\title{
Paideusis
}

\section{Notes on saying and showing, beauty, and other ideas of interest to art and education, with reference to Ludwig Wittgenstein}

\section{Stuart Richmond}

Volume 17, Number 2, 2008

URI: https://id.erudit.org/iderudit/1072433ar

DOI: https://doi.org/10.7202/1072433ar

See table of contents

Publisher(s)

Canadian Philosophy of Education Society

ISSN

0838-4517 (print)

1916-0348 (digital)

Explore this journal

Cite this article

Richmond, S. (2008). Notes on saying and showing, beauty, and other ideas of interest to art and education, with reference to Ludwig Wittgenstein. Paideusis, 17(2), 81-90. https://doi.org/10.7202/1072433ar

\section{Article abstract}

Conventionally, it is true an essay has a structure that moves progressively and logically from a beginning to a conclusion. In this group of small essays, I would like to explore my interests in the arts and education by working more with broad strokes, letting meanings emerge from passages in a less linear way, more like a collage, for example. Perhaps such an approach will be congenial for the arts, which are elusive, felt and expressive as much as conceptual. (c) Stuart Richmond, 2008

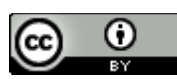

This document is protected by copyright law. Use of the services of Érudit (including reproduction) is subject to its terms and conditions, which can be viewed online.

https://apropos.erudit.org/en/users/policy-on-use/ 


\title{
notes on saying and showing, beauty, and other ideas of interest to art and education, with reference to Ludwig Wittgenstein
}

\author{
STUART RICHMOND \\ Simon Fraser University, Canada
}

\begin{abstract}
Conventionally, it is true an essay has a structure that moves progressively and logically from a beginning to a conclusion. In this group of small essays, I would like to explore my interests in the arts and education by working more with broad strokes, letting meanings emerge from passages in a less linear way, more like a collage, for example. Perhaps such an approach will be congenial for the arts, which are elusive, felt and expressive as much as conceptual.
\end{abstract}

posture

Though I had been thinking about possible topics before writing this, the material is not entirely planned. Much if not most of what is written emerged in process. There is a quality of indeterminacy about the work as a whole. I hope, therefore, that readers will feel free to draw out their own most suggestive or cogent meanings. I use "meanings" loosely to include feelings, allusions and memories as well as concepts. This looser approach appeals to me as giving more license and freedom of expression than would a standard academic form, and I am fortified by the work of, for example, Barthes and Wittgenstein, both of whom wrote using short passages, and paragraphs. Barthes' (1975) The Pleasure of the Text, is one example, Wittgenstein's (1974a) Philosophical Investigations is another. Susan Sontag (2001) writes a superb article on their "run on" writing methods, which certainly inspired me. I also took a lead from one remark of Wittgenstein's where he says, "I find it important in philosophizing to keep changing my posture, not to stand for too long on one leg, so as not to get stiff' (1980, p.27e). After writing in a more conventional vein for a long period, my approach in this paper is one way in which I can change my posture.

the amateur

The idea of the amateur conjures up some negative connotations in our age of specialization. The amateur is seen as one who lacks professional knowledge, is perhaps something of a dabbler or hobbyist. Yet, for many, an amateur interest can be a source of pleasure, a place of learning, and an opportunity to exercise skill and aesthetic judgment. And what, given the constraints of modern living, is wrong with a little enlightened dabbling? Ordinary people have long found spaces in their lives to devote a few hours to the pursuit of private interests, be they in gardening, games, cooking, walking, flower arranging, stamp collecting, photography, painting, nature study, or woodwork to

(C) Copyright 2008. The author, Stuart Richmond, assigns to Paideusis the right of first publication and educational and nonprofit institutions a non-exclusive license to use this document for personal use and in courses of instruction provided that the article is used in full and this copyright statement is reproduced. Any other usage is probibited without the express permission of the author. 
name a few. This tradition reflects the positive etymology of amateur as a lover, from the Latin amator, or French amare to love.

For many, amateur status offers an opportunity freely to follow interests, in their own time, for their own sakes, out of love. Amateurs are distinguished by their voluntariness, enthusiasm, and commitment. Amateurs can be solitary or band together in societies and clubs. The activities of amateurs are drawn from and are infused into local life and culture. The amateur way is democratic. People from different racial and cultural groups and genders, as well as the sick and housebound, can all be amateurs in some form. Amateur painters can be inspired by night classes, and by a new O'Keefe exhibition, but they live their own art, in their own lives, in their own ways, and according to particular circumstances. The important thing is the fact of participation. There is no need to worry particularly about fitting in with the latest international trends and theories or the need to make money, or to be intimidated by a lack of formal training. There is something liberating in amateur status. Being an amateur need not imply a deficiency. Local groups, such as choral and photographic societies often strive for very high standards. Most individuals sufficiently interested in devoting precious free time and expense to an activity realize that, if it is to be worthwhile, it will involve learning and practice. An amateur pursuit, a hobby, is more likely to maintain commitment if it offers challenge to mind and skill, sometimes body, creative expression, and is capable of stimulating a degree of emotional and aesthetic satisfaction. Being an amateur in some chosen area, a lover having intrinsic interests, is one way a person can free herself, if only a little, from the pain of living in a goal-driven, techno-market world. Ludwig Wittgenstein the philosopher was self-taught.

saying and showing

Ludwig Wittgenstein (1974b) drew an important distinction between saying and showing in the Tractatus Logico-Philosophicus, a book he wrote in the trenches during the first world war and later submitted as his doctoral thesis at Cambridge University. He later repudiated much of the book in favour of a more flexible, socially contextualized philosophy of language, but the distinction remains interesting and relevant today, especially for artists. The Tractatus is an austere, logical itemization of the supposed deep structure of language and its relation to the world. It is also an aesthetic work in that Wittgenstein was extremely concerned with its beauty and form, which was to mirror the idea that language, when analyzed, could be crystallized into a model of reality. The surprising key passages in the book, written almost at the end are, "We feel that even when all possible scientific questions have been answered, the problems of life remain completely untouched." (1974b, 6.521) And, "There are, indeed, things that cannot be put into words. They make themselves manifest. They are what is mystical." (1974b, 6.522). In his book on Wittgenstein, Edward Kanterian (2007) agrees that there is a distinction between what can be said by means of the language of propositions and science, which is what Wittgenstein meant, and what cannot be said. Kanterian points out that, "There are deep metaphysical truths, although they are strictly ineffable and can only be shown, indeed felt." (p.84). For Wittgenstein, matters concerning the meaning of life, ethics, aesthetics, religion and so on have this ineffable quality. As Kanterian observes, "This is the actual justification of the famous distinction between saying and showing." (P.83). But what does the distinction mean, and why is it of relevance for art? Wittgenstein is saying that metaphysical matters cannot be described scientifically or philosophically as we are not speaking of factual things in the world. Therefore philosophers should remain silent about and not attempt to theorize about such matters. This does not mean, however, that metaphysics is a closed book. Janik and Toulmin (1973) provide a very rich account of the ways in which, for Wittgenstein, the arts and the lives of ordinary people can show meaning and value.

Saying and showing have close affinities with content and form in art; and all of life, it should be remembered, has its variations of form. Portraits whether in paint or photographs reveal more than facial features. A good portrait is an image of character and experience, and thus has an ethical as well as an aesthetic dimension. The inexpressible, in Wittgenstein's terms, is reached through what can be expressed. Schulte, for example, notes in an essay on Wittgenstein and poetry, "What poetry can do is to put the expressible in such a way that something not expressible by the ordinary use of 
words is suggested to those readers who are alive to its allusions and can grasp and perhaps can reproduce them in a way that makes the signs come alive" (2004, p.161). In the movie, The Diving Bell and the Butterfly (2007), directed by Julian Schnabel, Jean-Dominiques Bauby, the editor of a Paris fashion magazine is suddenly paralyzed by a stroke. He wakes up in hospital to discover that while he can still see and hear, he can only blink his left eyelid. The doctors inform him that he has "locked in syndrome," the diving bell being a metaphor for his body, and that there is nothing they can do except wait and see. He realizes, however, that he has the freedom of his imagination (the butterfly), feelings and memories, and indeed he begins to write a book by blinking his eye in response to letters sounded out by an assistant, which is the autographical basis of the movie. Through subtle and haunting photography, the unspoken observation of what is taking place around him, his aliveness to his wife's beauty, the camera's frequent position of "looking outward," and snatches of his thoughts, imaginings, sensual feeling, and choice of music such as Charles Trenet's singing La Mer, the film shows the tragic beauty of the situation, Jean-Dominique's appreciation of his altered life, and realization of his wife's goodness and love especially after his girlfriend leaves the scene. We are quickly given the facts of the case, but mainly it is the way the film is fashioned expressively that shows, poetically, its real meaning. Interestingly, Schnabel, interviewed on the Charlie Rose Show (January 31, 2008, PBS), said he was trying to film something that was not factual. He struggled to answer the interviewer's direct questions about his method, which was largely intuitive.

I recognize something similar in what took place on a recent city walk as I entered into conversation with an old fellow with longish hair, a beard, jeans and a battered zippered jacket. He had his bag slung across one shoulder to the opposite hip, as I carry my own. Standing on a bridge I was looking down at the boats and water. "Don't jump," he said, smiling as he approached. Soon he was telling me about the time when ships were being built on the creek, about the cooper's shop, the engineering works where he had been a welder and about the old tree-lined streets with the small wooden houses, gardens, and front porches of his youth. He told me about jumping off Burrard Bridge at high tide as a kid. As he told his story his eyes shone, as he relived, nostalgically, the experience of his younger more innocent days. He was sharing his knowledge of local history but also showing feelings of pride in, loss of, the old life, of its daily activities and values in the face of a more dangerous and money-crazed city, though he never said as much. In art and life, content and form, saying and showing, fact and value are closely intertwined. Wittgenstein's distinction reminds us that the contours of the human spirit are revealed in artful form; indeed, one might say through the art of living.

\section{on subjectivity}

Perhaps it is the pressure of life in a society heavily influenced by science, economics, the market, models of learning, technology, and the media, that set out to capture, explain, govern, and sell back to us how we should think, act, desire, love, be, move, imagine, judge, appear, not discounting efforts to deconstruct the self, that prompts an impetus towards more expression of the subjective self, the sense of being alive in our own skins, of feeling more human, more personally present and in possession of our lives. I certainly feel this way and the work being done by university students in arts education in their projects and thesis writing has moved more in this direction. Here I am thinking of arts-based research as one example. Subjectivity is the defining quality of the self, the indexical I, the irreducible me-ness, the feeling of having a sensibility that gives rise to a personal point of view, an individual way of being and responding, a unique way of tasting life. Only I know intrinsically what it feels like to be me, in the first person. Subjectivity is thought and feeling combined. Could it be otherwise? How we think, who we are, is shaped by language, culture, and experience, but such influences are internalized and given shape and texture by each person. We have our own take on things. Toril Moi, a feminist scholar of literature, well travelled in the terrain of poststructuralist theory, refusing the liberal conception of the human subject, argues in an interview for a subject that she describes as "decentred" (p.142). Interestingly, however, she explains that "This is a subject that acts, and has responsibility, and that certainly exists. But it is also fragile, unstable, the 
product of its situation and in ceaseless interchange with that situation, which has to be understood as the body, as well as history, social structures, politics and so on." (p.142). Moi explains that she is interested in finding "different ways of thinking, ways...that allow me to say something I can believe in, that I can mean" (p.166). Earlier she noted, "My point is to turn intellectual work into a firstperson narrative," (p.143). At the end of the interview she stresses, "It is important to find a voice of one's own" (p.167). Obviously for Moi, the subject, a more ephemeral subject than the liberal subject, but a subject capable of responsibility nevertheless, lives, and furthermore, for her should have voice. Jacques Derrida, speaking on identity in an interview as part of the same book, observes, "Of course, when I pay attention to the possible breaks in identity I don't mean that we should not reaffirm, as much as possible, the identity, the self-identity which is the condition of responsibility" (p.25). He goes on to say that "we speak through a number of voices" (p.42) and that he would avoid seeing identity as something natural or having an ontology. Rather, he prefers to think of identity as a process of self-identification. Earlier in the interview he admits that despite what he says, writes and teaches, "My life is irreducible to what I say" (p.8) and that "I confess that everything that I oppose....in my texts, everything that I deconstruct-presence, voice, living, voice [sic] and so on-is exactly what I'm after in life. I love the voice, I love presence I love...,[sic] there is no love, no desire without it" (p.8). It is impossible to prove or disprove the existence of the self, or the precise ontological nature of the self, but unless we are damaged in some way, we all feel we have a self. Theory reminds us not to take too much for granted about who we are, or who we think we are, but as Derrida reminds us, who we are is not reducible to theory. For life, relationships, ethics, art, aesthetics, a creative feeling subject is necessary. There has to be a life behind a work of art or it could not be recognized as such. Having a voice is like discovering one's own self. Such selfexpression, which can be thought of as occurring in the daily work of teaching or art-making, for example, is an act of freedom, of setting forth, of making manifest, as Wittgenstein would say, the contours of one's personal sense of being. Unfortunately, such self-identifying freedom is not yet available to all.

Subjectively, one has one's own truth, not in the sense of disputing gravity but more in relation to emotion. Subjective truth is to do with how the individual experiences life. It may be true for one person that love proves impermanent but not for another. Subjectivity has long been thought to be a bad thing because it is the opposite of objectivity. But perhaps this is not, strictly, a helpful distinction as the shape of reality is always influenced by human perception. The subjective thinker, usually thought of as the novelist, journal writer, painter, dancer, and young person (though we are all inescapably subjective) responds to the world with intellect, feeling, imagination, and intuition intact. The subjective thinker, as Janik and Toulmin (1973) put it, "integrates life and thought," (p.178) in ways science and reason cannot reach. What is required in subjective expression is truth to life. We recognize in the "voice" of another the authentic speaking subject and that is something we can all identify with. There is no single truth or way of existing. Yet, in growing up, being ill, having a job, or being a parent, for example, individuals find common ground in shared patterns of experience and inter-subjective agreements concerning for example, what is true and good, or there could not be community, language, or art, etc. We may share a culture, indeed, no one can be a self, or find a voice in a vacuum, yet we also have our own singular ways of being. Loving someone means having a deep affection for his or her unique and irreplaceable qualities. Giving space in education for our subjective potentialities through activities such as the arts, language arts, history, geography, other languages, projects, visits, stories, field trips, school magazines, presentations, sometimes in collaboration with others, where affect and the aesthetic is valued, gives meaning to the education of the whole person, something sorely needed in our runaway world.

\section{trying on suits of armour}

I once taught a group of grade six boys with "behaviour problems." The school was in a small town in the foothills of the Canadian Rocky Mountains. Our classroom was in the basement, and the class had separate recess times from the other students in order to keep two groups separated. These boys 
had been expelled from their regular classes due to a combination of learning difficulties and disruptive behaviour. My instructions from the district superintendent were to "just do what you can." The first few weeks were challenging. Desks would be rocked as students got into conflict with one another, and sometimes with me as I sought to create some semblance of routine and order. I gradually built up a curriculum consisting of daily sports, mainly indoor floor hockey and soccer, math time, language arts and writing, stories read aloud by me (often from Jack London), and leathercraft.

One really good art project was making instruments out of cardboard, wood and paper mache for an air band. The boys performed "Eye of the Tiger" before the whole school during a Christmas concert, to great applause, which did wonders for their self-esteem. The boys expressed themselves freely through the medium of the musical performance giving vent to their subjective selves, something not usual in their somewhat constricted school lives. Also on one occasion I took the group on an overnight camp and mountain hike. This was part of a hunter training course, without the hunting or guns. We learned about various animals such as the pica and the hoary marmot, the white tailed deer, moose, grizzly, cougar, and bobcat; birds such as the grouse and the red-tailed hawk, plus plants and first aid, and the trip was to learn how to be in, and respect the wilderness. On another occasion we visited a city museum to see a collection of medieval armour. There was one suit they were allowed to try on. They learned how heavy it was to wear, and how difficult to see through the helmet's visor, or indeed to move about. Amazingly the suit was the right size showing how medieval knights were about the same height as grade six boys. My intent here was to show something radically removed from their immediate environment and experience, to stimulate their imagination and create new interests. While it was a stretch for these boys to grasp the idea of something medieval, used as they were to a diet of television, no books and little conversation at home, they were clearly stimulated by the experience. Later in class, they spent many hours researching and writing about medieval life and building models of castles.

A saving grace for me was the boys' keen interest in Harley Davidson motorcycles. Leathercraft lessons worked well here as they were able to make much prized wristbands and belts with the name "Harley" carved in. Gradually the boys came around. School was at least stable and supportive. The boys were vulnerable, each with pretty severe life difficulties. The Harley interest led to writing projects, science lessons, and engine drawings. Visits were arranged to a local Harley dealer where pamphlets could serve as research material — this was pre-computer days. Friday afternoons I showed a movie simply for entertainment, giving them a chance just to be together in a quiet and secure space. I sometimes think of these boys. The job was intense even though I only had six in the class. Speaking of leathercraft, fortunately I had some knowledge of the craft, as I had been inspired earlier by a book called Brendan's Leather Book, (Smith, 1972). I liked it because it was handwritten and included little line drawings of tools and processes and the interior of an old house in San Francisco, alive with cat and plants where the author lived. The book had a tone that was hippie cool—counter culture at the time.

\section{wu wei}

Alan Watts (1985) explains that the Tao of Taoism, a Chinese philosophy of life with close affinities to Zen Buddhism, means the way or process of life whose first and most important characteristic is spontaneity. "The Tao is accessible only to the mind which can practice the simple and subtle art of wu wer" says Watts (p.19). Wu wei means not-forcing, or non-striving; letting the mind work by itself, so as to release a spontaneous and creative intelligence known as te. Many will have experienced being blocked in art, writing, and various projects when the conscious mind tries too hard conceptually to impose a solution. $W u$ wei is more of an unconventional, easy does it, impromptu, observe and learn perspective in contrast to the goal-oriented, rule-governed, and assessment standards approaches prevalent in much of society, and according to Watts, it is the second most important principle of Taoism. In the arts and crafts of the East, "superior work has the quality of an accident," (p.28) notes Watts. Here one thinks of the bamboo brush and ink paintings and 
calligraphies which begin and end in one concerted motion, without touch ups. "What the culture of Taoism and Zen proposes," says Watts, "is that one might become the kind of person who, without intending it, is the source of marvelous accidents" (p.28).

I learned much from my Chinese colleagues on the value of non or indirect, ambiguous action in serving as dean of a faculty of arts, sciences and technology in a teacher education institute in Hong Kong. My instincts to react, intervene, and assert control had to be curbed in favour of more subtle, sensing the currents, nudging people on-side approaches. I learned much from these colleagues in response to the exigencies of the day but also in the ways they "handled" my unsuitable suggestions. Often a response would be a drawn out "yes" while they proceeded circuitously to hint at the opposite line of thinking.

Duncan Baker (2005) tells the story of R.H. Blyth, a university teacher of English literature who taught in Korea and Japan for several decades following the First World War. In the article, Baker quotes Blyth writing enigmatically of the Zen scholar Suzuki and his influence on himself: for example, "He who taught me all that I don't know," and "He who taught me not to teach" (2005, p.44). The latter is a remarkable sentiment in a teacher, and in his own teaching, Blyth was very free in his methods. He would often extemporize, quoting passages from books and poems from memory, seemingly unprepared, leaving room for the unexpected. In this sense there is no teaching as we understand it, only opportunities for students gradually to get the feel of things for themselves. Another example of this can be found in Herrigal's Zen in the Art of Archery (1989). As a student, Herrigel had to calm the will, learn to breathe, become purposeless, and be patient to understand the "artless" art of archery.

Blyth developed a love for haiku and Zen philosophy and writes: "Haiku shows us what we knew all the time but did not know we knew it; it shows us that we are poets in so far as we live at all" (cited in Baker, p.48). We become poets as we engage intrinsically and appreciatively with the realities and aesthetics of life. Blyth goes on to say:

"The essential simplicity of haiku and Zen must not be forgotten. The sun shines, snow falls, mountains rise and valleys sink, night deepens and pales into day, but it is only very seldom we attend to such things:

In the shop,

The paper-weights on the picture books;

The spring wind! —Kito

When we are grasping the inexpressible meaning of these things, this is life, this is living" (cited in Baker, pp. 48-49).

Such thoughts are not entirely alien in the west. In the Lecture on Ethics (cited in Janik and Toulmin, 1973), Wittgenstein notes, "Think, for example, of the wonder that anything whatever exists. This wonder cannot be expressed as a question, nor is there any answer to it" (p.194). Elsewhere, he observes that "philosophy ought really to be written only as poetic composition" (1980, p.24e). For Wittgenstein, a poetic sense is needed to understand the mutability of language used in different life forms. The inventiveness of a poet is needed to create a synoptic view of how language works in practice. Schroeder (2006) notes in reference to Wittgenstein's comments on philosophy as poetry, that Wittgenstein was interested in the flow and musicality of language, in attaining a certain naturalness and ease of expression, in the use of illuminating figures of speech and in making his work aesthetically appealing. Gerhard Richter, the German painter, observes, "Letting a thing come, rather than creating it—no assertions, formulations, inventions, ideologies-in order to gain access to all that is genuine, richer, more alive: to what is beyond my understanding" (1995, p.119). In his interview with Charlie Rose, noted earlier, it became clear that Schnabel entered the film set each day, prepared, but without any clear plan. With a few directions, he allowed things to begin and emerge, recording many personal contributions from the carefully chosen cast. For Schnabel the feeling of life given through expressive spontaneity was of primary importance. There is the sense, familiar to artists, that if things become too planned or over-rehearsed, some vital, experiential, formative quality 
risks being lost. This is true in life also. In preparing for external evaluations of new degrees in Hong Kong with colleagues, I learned, as dean, not to try to anticipate and practice answers to every possible question in favour of a more general preparedness, a freshness of mind, and a good team spirit.

\section{ethics and aesthetics}

Towards the end of the Tractatus, Wittgenstein (1974b) makes the statement "Ethics and aesthetics are one and the same" $(6.421$, p.86). No explanations are given. There is certainly an air of the mystical in this statement. Also, the statement itself might be seen as a contradiction of statement 7.00 seen below.

Janik and Toulmin observe, that for Wittgenstein, ethics and aesthetics are concerned with "right feelings" rather than "valid reasons"' (1973, p.198), with the meaning of life, with leading a good life, with what looks and feels right in art and the environment. Wittgenstein once raised the ceiling of a room a few centimeters in a house he had designed and completed for his sister, to make it harmonize proportionally. Tilghman (1991), drawing upon several passages from Wittgenstein in interpreting statement 6.421 says that both realms are ineffable or "unsayable" (p.64), both involve contemplation and are ends in themselves, and that "art is one of the most important ways in which ethical value can be shown" (p65). Here, Tilghman is thinking of art's power of expression. Schroeder's (2006) more limited interpretation, after drawing upon some complex arguments, is that ethics and aesthetics are both seen from a disinterested perspective, meaning that a subject is attended to for its own sake, putting aside personal or instrumental interests.

I explored the idea that for Wittgenstein there are deep metaphysical truths, including those of ethics and aesthetics, that cannot be put into words or codified in rules; they must be shown or made manifest. This idea stems from the saying and showing distinction, and his famous remark at the end of the Tractatus, "What we cannot speak about we must pass over in silence" (7.00, p.89) which was meant as a caution to theorizers in realms of value. In teaching it is helpful, however, to be able to discuss students' aesthetic responses to art and to what is the right thing to do in a situation of classroom conflict, for example. Wittgenstein (1980) would not disagree. He speaks quite freely about the arts and ethics in Culture and Value. Nevertheless, I think most would agree that in these areas, our responses, or the rightness of our responses cannot be made fully explicit or justified as proofs. While there are some norms in ethics and aesthetics; for example, "do not steal," and, "beauty lies in symmetrical proportions," such adages cannot address with certainty the complexity and uniqueness found in particular practical situations. Goodness and beauty, like art, cannot be defined once and for all. One might argue that rules, in any case, imperfect as they may be, come to an end in judgments. In practical situations we judge, act, proceed, by means of an imaginative leap of faith, that rules and criteria apply, that is, without further recourse to rules, or we should be in an infinite regress requiring rules for the rules and so on. Furthermore, we may feel empathy, pity, awe, love, and other emotions in particular lived situations that tend to elude language, rules and prescriptions. I was struck by Wittgenstein's comment on the wonder that anything whatever, exists, and that such cannot be put into a question. I have often felt this sense of wonder in exploring medieval architecture and nature. In an ethical or aesthetic situation, at some point, you have intuitively to feel your way to an understanding. As a practicing photographer, I have found that conceptual knowledge will only get me so far. How might I know by means of concepts or rules when looking through the camera's viewfinder, for example, that the framed subject will result in a good photograph? How might someone know with some certainty that they are having an aesthetic experience? Ethics and aesthetics are experiential concepts with all the subjectivities, meanings, and messiness of life. One further point: it seems true to me that in artistic practice, the mind is able to fuse knowledge with feeling in ways that cannot be captured in conceptual analysis. The same is true for ethical situations. Only in theory can it be possible to separate thought from feeling, meaning that our experience in ethics and aesthetics will be to some extent be "unsayable." 
Tilghman notes that for Wittgenstein, both realms involve contemplation. Schroeder uses the word "disinterested." Nowadays we are cautious about such terms if they imply being detached from personal history, affairs of the moment, political interests, or instrumental concerns. We are irrevocably subjective, influenced in thinking and response by, and enmeshed in, culture. So it is not clear here what is meant by the notion of disinterestedness, although, developed as he was by growing up in a wealthy family with interests in the arts and intellectual life, in turn of the century Vienna, it is reasonable to assume a Kantian influence, meaning as noted previously, the idea of attending to something for its own sake, putting aside personal or vested interests. Yet, even given our postmodern suspicions about the possibility of being disinterested in any pure sense, in ethics and aesthetics it is easy to see the inadvisability of responding with too much concern for self. How might one be compassionate if one's own needs are uppermost? How might a person see the subtle beauty in a painting of a mosque if she cannot dispel her religious prejudices? We are creatures of flesh and blood and we are fallible. But some disengagement from the affairs of the moment is required if our responses to, and experiences of life, aesthetics and art, are to be intrinsically meaningful and worthwhile. Disinterested does not mean unfeeling; indeed, feeling is at the heart of ethics and aesthetics for Wittgenstein, but without the possibility of some degree of "unselfing," as Murdoch (1971, p.82) puts it, there could be little possibility of love or appreciation.

Perhaps with the study of human situations in literature and the arts, in the students' own writing, in creative art work, art appreciation and art history, with examples from daily life, plus parental and teacher guidance, some sensitivity in responding to forms of value with an appropriate sense of detachment can be developed. I discussed at some length earlier how the arts engage and overlap with ethical concerns, which was one of Tilghman's points.

Some would argue, Oscar Wilde being one, that morality has nothing to do with art, that the two are separate realms. Recently I was shown a photograph of an imperial wizard of the Ku Klux Clan by Andres Serrano, or rather of a man in an imposing, anonymous, large white conical hood, facing magisterially the camera. There is no doubt that the image was awe-inspiring, medieval almost, warrior-like, beautiful some said. Leni Riefenstahl's Triumph of the Will is a brilliantly made film about the rise of the Nazis. And yet, when I remember the philosophies and activities of these subjects it becomes difficult for me to appreciate the works aesthetically, to see any beauty. Others might disagree. I would like to add that having seen the image of the "wizard," and a web video of Adolf Hitler galvanizing thousands of his followers into seig beil salutes I found it difficult to dislodge such scenes from my mind. They were there like stains in my consciousness. This raises issues for educators. On the one hand, freedom of artistic expression is very important, as is the right to see for oneself any artistic material; on the other hand, educators have to consider the potential effects of that material on young minds before exposure. Art certainly does embody and show situations of ethical import and this can range from good to evil. This leads me to suggest that there is one area in which ethics and aesthetics are not one, and that is in some ultimate sense in which humanity comes before aesthetics.

Imagine, for example, a photographer letting someone die while he or she gets a picture of that critical moment for an exhibition, or a person ignoring a desperate cry for help while they appreciate a recently purchased painting. Would we not agree that the need for compassion and protection come before art and aesthetics? I realize this is something to be judged in particular situations, but the basic idea holds true. This is not to say that a person could not be a good citizen and appreciate the arts, that the arts cannot sustain us through difficult passages of life, or are important to many in a meaningful life. It is to say that if it comes to a serious choice, ethics is primary. Wittgenstein's statement requires us to think about these matters, especially the important shared terrain between the two concepts.

\section{art education}

Art is more or less tolerated in the general school curriculum. This position of secondary importance is not altogether a bad thing because it allows students and teachers to work in relative peace, 
unhindered by attempts to create some sort of accountable technology out of it. The drive for control and measurement does not work in art anymore than it works in other complex human situations, whatever the scientists tell us. The lack of definition for art—due to its endlessly varied and evolving character-is not especially problematic. Mainly it confers a certain openness and freedom of thought. Artistic practice carries on without a firm general concept, incorporating whatever ideas, skills and media appeal to the artist's needs and values at the time. Of course, historical attempts to define art as imitation or as form, for example, and living patterns of practice still serve to inform thinking.

But what might be the role of art education in the contemporary world? Clearly there is a need for the social and philosophical critique of politics, advertising, education, gendering, postcolonial experience, technology, environmental degradation, racial and sexual prejudice, global marketing, the commodification of art, and religious conflict, among many other pressing concerns. But the theoryladen approaches of contemporary conceptual art, if practiced in isolation, risk losing the more aesthetic, skillful, expressive and intuitive responses that satisfy the heart.

In expressive work, students fuse their own feelings and ideas into a subjective, aesthetic shaping of visual imagery. Some expressiveness, or personal rendering is inevitable even with representation because a work stems, necessarily, from the sensibility of a particular artist. As noted, there is a life behind a work of art. We can think of expression as a poetics of art. But as Suzanne Langer points out, "No theory can set up criteria of expressiveness.... If it could we could learn to make poetry or paint pictures by rule" (1953, p.407). The challenge of the blank canvas with its calling forth of imaginative insights, spontaneous rather than willed, can serve to temper the instrumental self. Teaching proceeds mainly by example, demonstration, suggestion, and free exploration. But nowadays it is possible to re-work visual material endlessly through computer programs so as to remove all "flaws," in search of a mythical perfection and in so doing, risk the diminishment of uniqueness and expressive energy. Here is the timely lesson from the East: preserve the original human touch at the risk of some spilt ink, and promote aesthetic responsiveness. There is a place for beauty in art, for the development of ineffable understanding and intrinsic enrichment of life.

\section{References}

Baker, D. (2005). Remembering R.H. Blyth. Kyoto Journal: Perspectives from Asia, 59, pp. 42-29.

Barthes, R. (1975). The pleasure of the text (R. Miller, Trans.). New York: Hill and Wang.

Derrida, J. (2003). Following theory: Jacques Derrida (an interview with N. Royle, S. Woods, \& C. Norris). In M. Payne \& J. Schad, (Eds.), life.after.theory (pp. 1-51). London and New York: Continuum.

Herrigel, E. (1989). Zen in the art of archery. (D.T. Suzuki, Intro.; R.F.C. Hull, Trans.). New York: Vintage.

Janik, A. \& Toulmin, S. (1973). Wittgenstein's Vienna. New York: Simon and Schuster.

Kanterian, E. (2007). Ludwig Wittgenstein. London: Reaktion Books.

Langer, S. (1953). Feeling and form. London: Routledge and Kegan Paul.

Moi, T. (2003). Feminist theory after theory: Toril Moi (an interview with M. Payne). In M. Payne \& J. Schad, (Eds.), life.after.theory (pp.133-167). London and New York: Continuum.

Murdoch, I (1970). The sovereignty of good. London and New York: Routledge.

Richter, G. (1995). Gerhard Richter the daily practice of painting: Writings and interviews 1962-1993. (H.-U. Obrist, Ed. \& D. Britt, Trans.).Cambridge Mass: MIT Press/Anthony d'Offay Gallery London.

Schroeder, S. (2006). Wittgenstein: The way out of the fly bottle. Cambridge, UK: Polity Press

Schulte, J. (2004). "The Life of the Sign:" Wittgenstein on reading a poem. In J. Gibson \& W. Huemer, (Eds.), The literary Wittgenstein (pp.146-164). London and New York: Routledge

Smith, B. (1972). Brendan's leather book. Cotati, CA: Outer Straubville Press. 
Sontag, S. (2001). Writing itself: On Roland Barthes. In Where the stress falls (pp.63-88). New York: Picador.

Tilghman, B. R. (1991). Wittgenstein, ethics and aesthetics: The view from eternity. London: Macmillan.

Watts. A. (1989). The way of Zen. New York: Vintage.

Wittgenstein, L. (1980). Culture and value. (G.H. von Wright \& H. Nyman, Eds. \& P. Winch, Trans.). Chicago: University of Chicago Press.

Wittgenstein, L. (1953/1974a). Philosophical investigations. (G.E.M. Anscombe, Trans.). Oxford: Basil Blackwell.

Wittgenstein, L. (1921/1974b). Tractatus logico-philosophicus. (D.F. Pears \& B.F. McGuinness, Trans.). London and New York: Routledge.

\section{About the Author}

Stuart Richmond is a professor of arts education at Simon Fraser University. He can be reached at stuart_richmond@sfu.ca 